\title{
Bibliografia prac prof. Zenona Leszczyńskiego opublikowanych w latach 2003-2021
}

Bibliografię prac prof. dra hab. Zenona Leszczyńskiego opublikowanych w latach 1954-2002 zestawili Agnieszka Karolczuk i Zygmunt Gałecki ${ }^{1}$. Ukazała się ona w tomie „Roczników Humanistycznych” przygotowanych na jego siedemdziesięciolecie. Niniejsze zestawienie obejmuje prace od roku 2003, wraz z jedną pracą z roku 2002, która nie została uwzględniona $\mathrm{w}$ tamtym spisie. Przy przygotowywaniu poniższego zestawienia, korzystałem z katalogów Biblioteki Narodowej, Biblioteki KUL i Biblioteki Uniwersytetu w Białymstoku oraz z internetowych wyszukiwarek i ogólnodostępnych serwisów, np. Google Scholar (https://scholar. google.pl), iSybislaw (http://www.isybislaw.ispan.waw.pl/) etc. Dziękuję także prof. Agnieszce Leszczyńskiej, córce Zenona Leszczyńskiego, za pomoc $\mathrm{w}$ dotarciu do niektórych prac i informacji bibliograficznych.

\section{PUBLIKACJE}

Wokół izomorfy onomastycznej, [w:] Dialektologia jako dziedzina językoznawstwa i przedmiot dydaktyki. Ksiegga jubileuszowa dedykowana profesorowi Karolowi Dejnie, red. S. Gala, Łódzkie Towarzystwo Naukowe, Łódź 2002, s. 287-293.

1 A. Karolczuk, Z. Gałecki, Bibliografia prac Zenona Leszczyńskiego opublikowanych w latach 1954-2002, „Roczniki Humanistyczne” 2001-2002, t. XLIX-L, nr 6, s. 9-22. 
2003

Nazwiska a nazwy zbóż, w: Język polski. Współczesność, historia, t. 4, red. W. Książek-Bryłowa, H. Duda, Towarzystwo Naukowe Katolickiego Uniwersytetu Lubelskiego, Lublin 2003, s. 285-288.

Polska geografia językowa w służbie diachronii, „Poznańskie Spotkania Językoznawcze" 2003, t. 11, s. 51-60.

Ten-o, o-taki, tu-o-idzie..., w: Słowa jak mosty nad wiekami, red. U. Sokólska,

P. Wróblewski, Wydawnictwo Uniwersytetu w Białymstoku, Białystok 2003, s. 273-279.

Wspomnienie o Bogusławie Krei, „Roczniki Humanistyczne” 2003, t. LI, z. 6, s. 9-15.

2004

Czy istnieje potencjalna możliwość akceptacji dorostych kobiet?, „Annales Academiae Paedagogicae Cracoviensis. Studia Lingustica" 2004, t. 19, nr 2, s. 227-229.

O emocjonalnej perswazji w tekście naukowym, „Rozprawy Komisji Językowej" 2004, 49, s. 257-262.

2005

Dyskusja nad referatami Stanisława Grabiasa i Krystyny Skarżyńskiej, w: Bariery $i$ pomosty $w$ komunikacji językowej Polaków, red. J. Bartmiński, U. Majer-Baranowska, Wydawnictwo Uniwersytetu Marii Curie-Skłodowskiej, Lublin 2005, s. 68-83. Głos Z. Leszczyńskiego na s. 72.

Dyskusja nad referatami Walerego Pisarka i Jerzego Bartmińskiego, w: Bariery i pomosty w komunikacji językowej Polaków, red. J. Bartmiński, U. Majer-Baranowska, Wydawnictwo Uniwersytetu Marii Curie-Skłodowskiej, Lublin 2005, s. 347-352. Głos Z. Leszczyńskiego na s. 347-348.

2007

Rzut oka na babę i łańcuszek wynikajacych przy tym zjawisk, "Białostockie Archiwum Językowe" 2007, nr 7, s. 99-113.

2008

Dyskusja nad referatami W. Pisarka i T. Wicherkiewicza (Adam Pawłowski, Zenon Leszczyński, Krystyna Mazur, Jerzy Bartmiński, Tadeusz Zgółka), 
w: Polska polityka językowa w Unii Europejskiej, red. J. Warchala,

D. Krzyżyk, Wydawnictwo Uniwersytetu Śląskiego, Katowice 2008,

s. 108-111. Głos Z. Leszczyńskiego na s. 108-109.

Dyskusja [nad referatem Andrzeja Piotrowskiego]: Zenon Leszczyński, Jerzy Bralczyk, Jerzy Bartmiński [i inni], w: Polska polityka językowa w Unii Europejskiej, red. J. Warchala, D. Krzyżyk, Wydawnictwo Uniwersytetu Śląskiego, Katowice 2008, s. 254-272. Głos Z. Leszczyńskiego na s. 254.

O eufemizmach i quasi-eufemizmach $w$ Trylogii (szczególnie w wypowiedziach Zagłoby), w: Tabu językowe i eufemizacja w dialektach słowiańskich, red. F. Czyżewski, A. Tyrpa, Wydawnictwo Uniwersytetu Marii Curie-Skłodowskiej, Lublin 2008, s. 169-180.

2010

Buczacz - wyraz tabu?, w: Z lubelskich badań nad stowiańszczyzna wschodnia: ksiegga dedykowana profesorowi Michałowi Łesiowowi, red. D. Nowacka i in., Wydawnictwo KUL, Lublin: 2010, s. 67-71.

Kazimierz Nitsch $z$ daleka $i$ z bliska, w: Studia dialektologiczne, t. IV, red. H. Kurek, A. Tyrpa, J. Wronicz, Polska Akademia Nauk. Instytut Języka Polskiego, Kraków 2010, s. 35-46.

2011

Spotkania z Maria Kamińska, w: Profesor Maria Kamińska, red. D. Bieńkowska, E. Umińska-Tytoń (Sylwetki Łódzkich Uczonych, z. 106), Łódzkie Towarzystwo Naukowe, Łódź 2011, s. 37-41.

2012

O Tadeuszu Brajerskim historyku języka, w: Nasi Mistrzowie. Z dziejów językoznawstwa polonistycznego w Katolickim Uniwersytecie Lubelskim, red. Z. Gałecki, Wydawnictwo KUL, Lublin 2012, s. 47-58.

2013

Jedna jaskółka wiosny nie czyni, ale lepszy rydz niż nic, w: Mówię, więc jestem, t. 4, red. M. Milewska-Stawiany, E. Rogowska, Wydawnictwo Uniwersytetu Gdańskiego, Gdańsk 2013, s. 162-166. 
2014

Prof. Tadeusz Brajerski, „Gazeta Wyborcza” 5 IV 2014 („Gazeta Stołeczna”, s. 12). Internet: https://classic.wyborcza.pl/archiwumGW/7867323/ Prof-Tadeusz-Brajerski. We współpracy z Ireną Winkler-Leszczyńską.

2015

Uwagi co do okoliczności zaproszenia docenta Mariana Kucały na KUL w 1974 roku, „Roczniki Humanistyczne” 2015, t. LXIII, z. 6, s. 356-358.

2016

Uwagi o zmianach w "Słowniku poprawnej polszczyzny" Stanisława Szobera, w: Dawne z nowym łącząc... In memoriam Mariani Kucała, red. J. Klimek-Grądzka, M. Nowak, Towarzystwo Naukowe KUL: Katolicki Uniwersytet Lubelski Jana Pawła II, Lublin 2016, s. 229-240.

2020

Polonistyka kulowska w latach 1949-1954 w oczach ówczesnego studenta. Początki Sekcji Językoznawczej Koła Polonistów Studentów KUL, w: Koło Polonistów S. K.U.L 1919-2019. Szkice, wspomnienia, materiały, red. A. Fitas, Wydawnictwo KUL, Lublin 2020, s. 55-61.

\section{PRACE REDAKCYJNE}

„Białostockie Archiwum Językowe”. Uniwersytet w Białymstoku. Wydział Filologiczny. Członek komitetu redakcyjnego od t. 1 (2001) do 20 (2020).

„Roczniki Humanistyczne”. Towarzystwo Naukowe KUL. Lublin. Redaktor nacz. Od r. 2003 członek rady naukowej pisma. 